MINIREVIEW
Minireviews provides an opportunity to summarize existing knowledge of selected ecological areas, with special emphasis on current topics where rapid and significant advances are occurring. Reviews should be concise and not too wide-ranging. All key references should be cited. A summary is required.

\title{
Habitat coupling in lake ecosystems
}

\author{
Daniel E. Schindler and Mark D. Scheuerell
}

Schindler, D. E. and Scheuerell, M. D. 2002. Habitat coupling in lake ecosystems. Oikos 98: 177-189.

\begin{abstract}
Lakes are complex ecosystems composed of distinct habitats coupled by biological, physical and chemical processes. While the ecological and evolutionary characteristics of aquatic organisms reflect habitat coupling in lakes, aquatic ecology has largely studied pelagic, benthic and riparian habitats in isolation from each other. Here, we summarize several ecological and evolutionary patterns that highlight the importance of habitat coupling and discuss their implications for understanding ecosystem processes in lakes. We pay special attention to fishes because they play particularly important roles as habitat couplers as a result of their high mobility and flexible foraging tactics that lead to inter-habitat omnivory. Habitat coupling has important consequences for nutrient cycling, predator-prey interactions, and food web structure and stability. For example, nutrient excretion by benthivorous consumers can account for a substantial fraction of inputs to pelagic nutrient cycles. Benthic resources also subsidize carnivore populations that have important predatory effects on plankton communities. These benthic subsidies stabilize population dynamics of pelagic carnivores and intensify the strength of their interactions with planktonic food webs. Furthermore, anthropogenic disturbances such as eutrophication, habitat modification, and exotic species introductions may severely alter habitat connections and, therefore, the fundamental flows of nutrients and energy in lake ecosystems.
\end{abstract}

D. E. Schindler, M. D. Scheuerell, Dept of Zoology, Univ. of Washington, Box 351800, Seattle,WA 98195, USA (deschind@u.washington.edu).

A current emphasis in ecology stresses the interactions among spatially segregated habitats (Polis et al. 1997). Discontinuous habitats are coupled by organism movements, gravity, water flow and air flow, which generate fluxes of predators and prey, detritus and nutrients among spatially distinct habitats. Ecological dynamics in localized areas are often driven by inputs of nutrients and energy from distant or adjacent habitats. Prominent examples include: coastal stream and riparian food webs are subsidized by massive inputs of marinederived nutrients associated with salmon carcasses following spawning migrations (Willson et al. 1998); small streams in forested watersheds derive most of their organic material from the litterfall from surrounding terrestrial vegetation (Fisher and Likens 1973, Gregory et al. 1991); invertebrate production from terrestrial and aquatic habitats reciprocally subsidizes aquatic and terrestrial predators in stream and riparian habitats

Accepted 12 March 2002

Copyright (C) OIKOS 2002

ISSN 0030-1299

OIKOS 98:2 (2002) 
(Nakano and Murakami 2001); marine carrion and detritus that washes up on small islands provides the trophic base for terrestrial consumers which control the community structure and species composition of islands in the Gulf of California (Polis et al. 1998); and daily foraging migrations by waterfowl transport substantial quantities of nitrogen and phosphorus from agricultural fields into roosting wetlands (Kitchell et al. 1999). In studies of lake ecosystems, an extensive literature describes the controls and consequences of geochemical fluxes from watersheds to lakes (e.g. Hasler 1975, Likens 1985). However, we argue that aquatic sciences have a poor understanding of the causes and consequences of ecological coupling among the pelagic (open-water), benthic (bottom-associated) and riparian (shoreline) habitats of lakes. Recent papers have reviewed the importance of linkages between above-sediment and below-sediment processes for the maintenance of freshwater biodiversity (Lake et al. 2000, Palmer et al. 2000). Covich et al. (1999) reviewed the roles of benthic invertebrates in freshwater ecosys- tem processes and biodiversity. The purpose of this paper is to review several key ecological processes that functionally link discontinuous habitats in lakes. We emphasize several ecological and evolutionary patterns that demonstrate that coupling among various habitats of lakes is critical for maintaining processes that control overall ecosystem structures and functions. We finish by highlighting several anthropogenic impacts on benthic and riparian habitats of lakes that may seriously impair natural patterns of habitat coupling in lakes.

\section{Lakes as systems of interacting habitats}

Lakes are complex ecosystems composed of several distinct subsystems or habitats (Fig. 1). The physical and chemical structure of the pelagic habitat of lakes is relatively homogeneous in the horizontal dimension, but can have substantial vertical heterogeneity associated with thermal and chemical stratification. The biota that inhabit the pelagic habitats of lakes include micro-

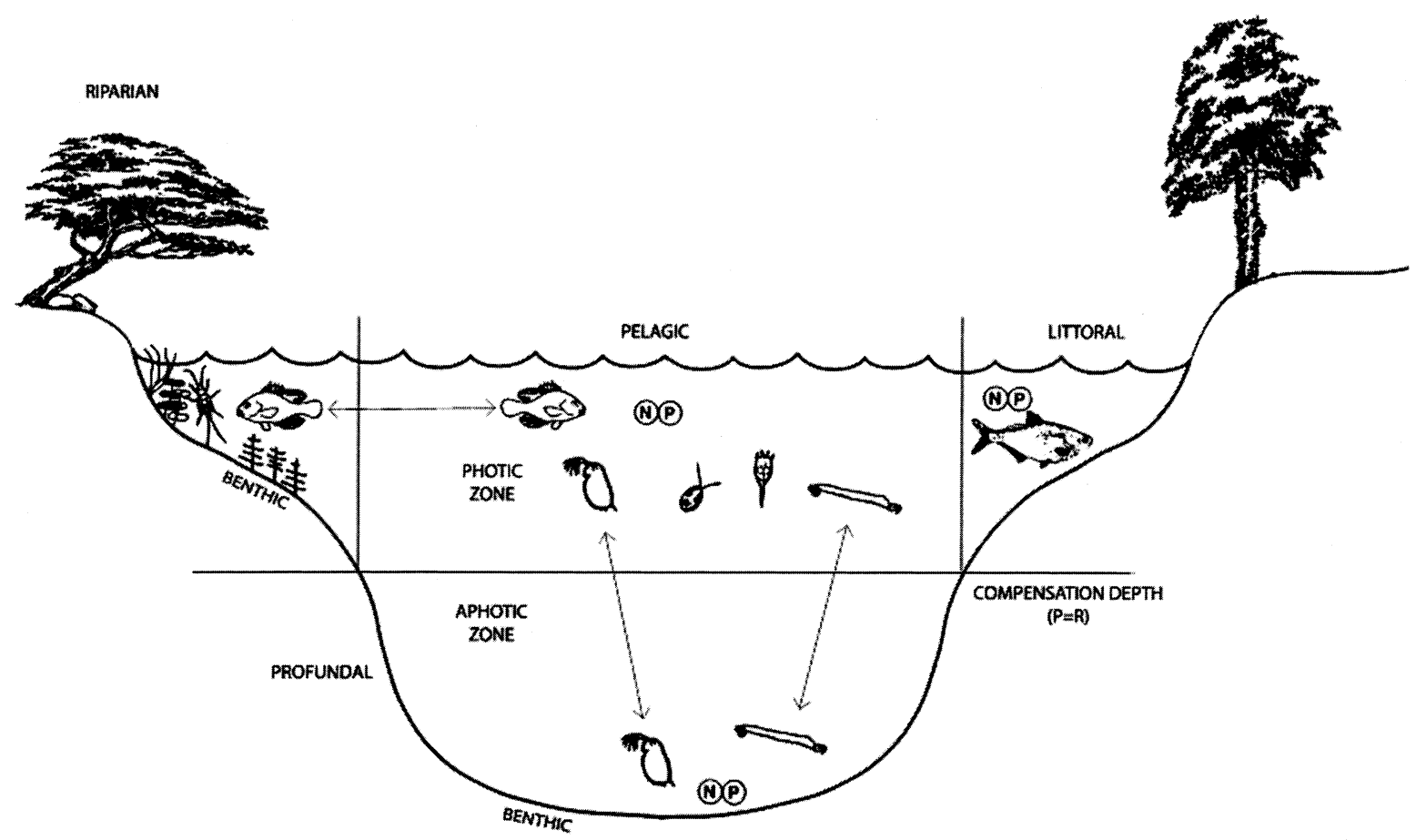

Fig. 1. Schematic of a lake as an integrated system of coupled habitats. The major features that distinguish the habitats are described below. Redrawn from Vanni (1996) (with permission).

Benthic habitats are those associated with bottom substrate in lakes.

Pelagic habitats are the open-water components of lakes and are often assumed to interact weakly with benthic and riparian habitats.

Littoral zones are nearshore, shallow habitats where water depth is less than the compensation depth. Compensation depth is defined as the depth at which there is sufficient light for photosynthesis to balance respiration. Thus, production in littoral habitats is driven by autotrophic processes.

Profundal zones are habitats located deep in the water column, below the average compensation depth. Heterotrophic processes drive production in profundal habitats, especially by consumption of sedimented organic matter produced in surface habitats. Riparian habitats are located at the land-water margin. The habitats are usually considered as part of the terrestrial system because they are inhabited by non-aquatic plants, but they are intimately linked to aquatic habitats through animal movements, and coarse and fine litter deposition. 
scopic bacteria, viruses, protozoa, phytoplankton, zooplankton, planktonic life-stages of insects, and fishes. Pelagic habitats are inhabited predominantly by planktonic organisms. Energy flow in this habitat is largely through phytoplankton and bacterial pathways. Benthic habitats of lakes are associated with bottom substrata and can be substantially heterogeneous in both vertical and horizontal dimensions (Lodge et al. 1988). This heterogeneity is associated with physical structure created by sediments, rocks, aquatic plants and woody debris from riparian habitats (Eschmeyer 1936, Christensen et al. 1996, Covich et al. 1999), and steep chemical gradients within the sediments. The dominant taxa in benthic habitats are algae (periphyton and metaphyton), macrophytes, bacteria, protozoa, an impressive diversity of aquatic insects and other invertebrates, and fishes. Other vertebrates like amphibians, reptiles, and mammals and birds can be important in some systems. Energy flow in benthic food webs is arguably more complicated than in planktonic habitats. The main energy sources for benthic secondary production include primary production from benthic algae and macrophytes, allochthonous inputs from surrounding terrestrial systems and sedimentation of plankton (Strayer and Likens 1986, Covich et al. 1999). Riparian habitats are the transition zones between terrestrial and aquatic systems. The vegetation in these habitats is composed of terrestrial plants that are usually adapted to high disturbance regimes and wetted soils (Naiman and Décamps 1997). Riparian habitats contribute substantial inputs of organic material (particulate and dissolved) and large woody debris to the aquatic systems they interface with.

Despite the acknowledgement from aquatic ecologists that benthic habitats are a critical component of lentic ecosystems, limnology has been dominated by research concerning the pelagic habitats of lakes. Studies of the riparian habitats of lakes are nearly absent. In this article, we describe a set of processes that functionally link the ecological dynamics of benthic, riparian and pelagic habitats of lakes. We refer to these processes collectively as ecological habitat coupling. We also emphasize that habitat coupling may create situations where the dynamics observed in one habitat (e.g. pelagic) may often be driven by processes that occur in another habitat (e.g. benthic and riparian). Current paradigms in lake ecology and management do not sufficiently embrace these linkages, which may limit their generality and utility.

\section{Most lakes are small and shallow}

Wetzel (1990) presented a global survey of the sizes of bodies of standing water to demonstrate that most of the world's lakes are small $\left(<1 \mathrm{~km}^{2}\right.$ surface area) and shallow ( $<10 \mathrm{~m}$ mean depth) (Fig. 2). For most lakes of the world, perimeter:area and area:volume ratios are relatively high thus producing considerable potential for habitat coupling because these systems are less dominated by a single habitat type. Therefore, biological, chemical and physical interactions of pelagic habitats with benthic and riparian habitats have the potential to be substantial in most lakes based on geometric arguments alone (Wetzel 1990).

It should not be surprising that habitat coupling is important in lakes when we consider broad patterns in the geometry of the world's lakes (Wetzel 1990). The ratio of edge to volume establishes the physical potential for habitat coupling in ecosystems (Wiens et al. 1985, Polis et al. 1997). Ecological interactions between benthic, riparian and pelagic habitats should be most important in lakes with high perimeter:area ratios. Small and shallow lakes should have the strongest coupling between benthic and pelagic habitats because the perimeter:area ratio generally increases as lake surface area and depth decrease. Large lakes are also coupled to their watersheds but these effects are probably localized near the inflows of rivers. Limnologists have developed empirical models that relate various aspects of lake productivity to lake geometric indices. One of these models is the morphoedaphic index that describes a positive relationship between fish production and the ratio of total dissolved solids:mean depth of the lake (Ryder 1965). Thus, shallow lakes tend to be more productive per unit of area than deep lakes with equivalent concentrations of dissolved materials. Some of the inverse relationship between the depth of lakes and fish production might result from the fact that shallow lakes are generally warmer than deep lakes.
Fig. 2. Frequency distributions of surface area, depth and the relative contributions of littoral and pelagic habitats for lakes worldwide (redrawn from Wetzel 1990, with permission).
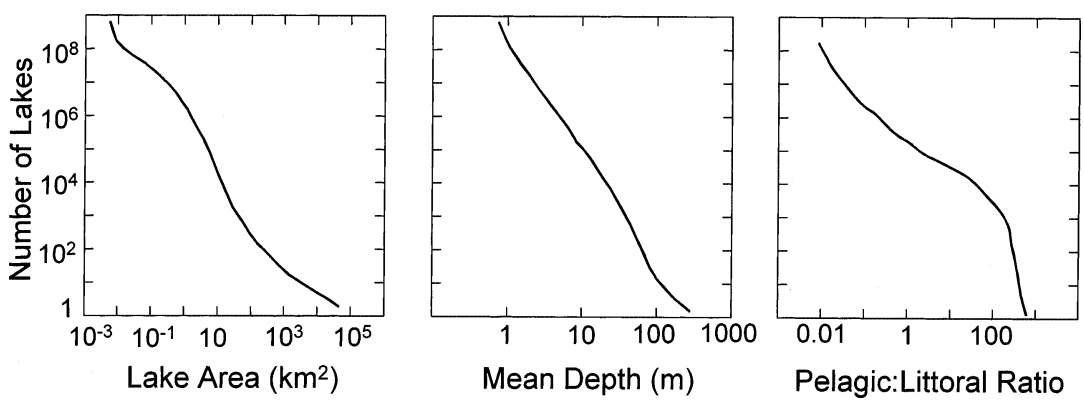
However, a second reason for increased fish production in shallow lakes might be increased benthic productivity and increased access for fishes to productive benthic habitats (Hanson and Leggett 1982). A second informative metric is the shoreline development index that describes the degree of shoreline convolution relative to a circle (Wetzel 1990). Lakes with a high degree of shoreline convolution have stronger ties to riparian habitats because of the increased perimeter:area ratio and therefore receive more terrestrial inputs of nutrients and organic matter (Gasith and Hasler 1976). In essence, the importance of riparian-lake coupling is positively related to the perimeter:volume ratio of lakes. Thus, there is a strong geometric precedence for the importance of habitat coupling because most of the worlds lakes are relatively small and shallow.

\section{Habitat coupling in aquatic ecosystems}

Here, we highlight some of the important ecological processes that link discontinuous habitats in lakes to demonstrate the potentially serious limitations of a non-integrated approach in aquatic ecology. While some pelagic processes can have important effects on benthic processes, we emphasize that many of the ecological processes that are studied exclusively in pelagic habitats may be regulated by critical, unidirectional interactions from benthic systems. Linkages between riparian and aquatic components of lake ecosystems are also potentially strong but generally overlooked.

The most prominent directional effects of pelagic habitats on benthic systems involve the deposition of planktonic material onto the benthos, and interception of light and nutrients in the water column before they reach benthic organisms (Table 1). For example, in Lake Michigan, USA, sedimentation of phytoplankton is the major carbon resource for production of benthic amphipods (Diporeia; Fitzgerald and Gardner 1993). These amphipods represented $65 \%$ of total benthic invertebrate biomass (Nalepa 1989) and are one of the major prey sources for pelagic fishes (Wells and Beeton 1963, Stewart and Binkowski 1986). In other systems, sedimentation of phytoplankton-produced organic matter provides the main energy source to profundal invertebrates (Covich et al. 1999) but the relative importance of this energy flux is likely proportional to the depthand time-integrated planktonic production in the water column. Phytoplankton can also regulate productivity of benthic periphyton and macrophytes by intercepting light and limiting nutrients in the water column of lakes (Sand-Jensen and Borum 1991). Phytoplankton biomass can be sufficiently high in lakes with high nutrient concentrations such that they effectively shade

Table 1. Examples of important mechanisms for habitat coupling in lake ecosystems. Footnotes for each process indicate relevant references.

\begin{tabular}{|c|c|}
\hline Process & Description \\
\hline \multicolumn{2}{|l|}{ Directional pelagic to benthic } \\
\hline Sedimentation $^{1}$ & $\begin{array}{l}\text { Organic matter produced through plankton production can form the basis for a } \\
\text { substantial component of benthic secondary production, and is the major output } \\
\text { of nutrients from the water column. }\end{array}$ \\
\hline Light interception ${ }^{2,4}$ & $\begin{array}{l}\text { Phytoplankton and dissolved organic matter (DOM) in the water column can } \\
\text { control the amount of sunlight that is available for benthic primary producers. }\end{array}$ \\
\hline Nutrient interception ${ }^{3,4}$ & $\begin{array}{l}\text { Phytoplankton compete with benthic algae for limiting nutrients. Because boundary } \\
\text { layers can limit diffusion to benthic algae, phytoplankton often have the } \\
\text { advantage in obtaining limiting nutrients. }\end{array}$ \\
\hline Pelagic prey for benthic predators ${ }^{5}$ & $\begin{array}{l}\text { Benthic invertebrates such as zebra mussels filter pelagic phytoplankton and small } \\
\text { zooplankton and recycle nutrients to the benthos. }\end{array}$ \\
\hline \multicolumn{2}{|l|}{ Directional benthic to pelagic } \\
\hline Benthic prey for pelagic predators ${ }^{6,7}$ & $\begin{array}{l}\text { Benthic algae, invertebrates, and fishes serve as prey for pelagic predators. This } \\
\text { benthic food subsidy stabilizes fish population dynamics. }\end{array}$ \\
\hline Internal nutrient loading $g^{8,9,10,11}$ & $\begin{array}{l}\text { The direct remineralization of nutrients from lake sediments or the indirect supply } \\
\text { through macrophyte senescence and grazing provides additional sources of } \\
\text { limiting nutrients to pelagic nutrient cycles. Similarly, the metabolic activity of } \\
\text { benthic invertebrates and fishes also recycles nutrients and makes them available } \\
\text { for phytoplankton growth. }\end{array}$ \\
\hline Spawning habitat ${ }^{12}$ & $\begin{array}{l}\text { Fishes that consume plankton commonly build spawning nests out of sand, gravel, } \\
\text { woody debris, or vegetation, thus are dependent on benthic habitats. Insects often } \\
\text { lay eggs on littoral vegetation and litter. }\end{array}$ \\
\hline Refuge habitat ${ }^{13,14,15}$ & $\begin{array}{l}\text { Many small fishes that consume plankton use benthic habitats as predation refuges. } \\
\text { Zooplankton and phytoplankton also use benthic sediments as a refuge through } \\
\text { the production of diapausing eggs or cysts. }\end{array}$ \\
\hline${ }^{1}$ (Covich et al. 1999) & ${ }^{6}$ (Schindler et al. 1997b) \\
\hline${ }^{2}$ (Scheffer et al. 1993) & ${ }^{7}$ (Stein et al. 1995) \\
\hline${ }^{3}$ (Sand-Jensen and Borum 1991) & ${ }^{13}$ (Werner et al. 1983) \\
\hline 4 (Vadeboncoeur et al. 2001b) & ${ }^{9}$ (Boers et al. 1991) \\
\hline${ }^{5}$ (MacIsaac et al. 1992,1995$)$ & ${ }^{15}$ (Rengefors et al. 1998) \\
\hline
\end{tabular}


out benthic algae and macrophytes (Scheffer et al. 1993). Although rooted macrophytes obtain most of their nutrients through root uptake from sediments, periphyton often compete with planktonic algae for limiting nutrients such as phosphorus and nitrogen (Sand-Jensen and Borum 1991).

Despite such studies, we believe that many important components of benthic-pelagic coupling at the ecosystem scale are directional from benthic to pelagic habitats in lakes (Table 1). For example, remineralization of nutrients and carbon from lake sediments can represent a major internal input to water column nutrient cycles (Wetzel 1979). The metabolic and burrowing activities of benthic invertebrates may enhance this benthic nutrient regeneration in certain circumstances (Nalepa et al. 1983, Boers et al. 1991) or impede it in others by aerating sediments. Aquatic macrophytes also move substantial quantities of nutrients out of the sediments and into their own tissues, which are then released following consumption or senescence and decomposition of the plants (Carpenter 1980, Barko and Smart 1980, Smith and Adams 1986).

\section{Fishes link benthic and pelagic habitats}

A common model of aquatic communities is a linear chain of interactions that progress from phytoplankton (primary producers), through zooplankton grazers to planktivorous fishes and then eventually to piscivorous fishes (e.g. Persson et al. 1992). This view of aquatic communities generally assumes that pelagic food webs are largely independent of benthic systems and that dynamics of pelagic systems are determined by internal processes and interactions with the physical/chemical environment. We argue that this model has limited applicability to most lake ecosystems because it seriously under-represents the importance of benthic food webs and riparian inputs for the structure and dynamics of pelagic systems. Although interactions among planktonic species may be effectively isolated from benthic and riparian habitats at certain times and in some ecosystems, these certainly do not occur in isolation of the effects of fishes that are often strongly dependent on benthic and terrestrial food sources.

Because fishes are very mobile organisms, they can effectively participate in both benthic and pelagic food webs and, therefore, link these two ecological systems through inter-habitat omnivory. Despite the extensive literature that has developed around the effects of fishes on lake food webs and ecosystem processes, very few studies have effectively linked benthic and pelagic habitats within a food web perspective of lakes (Lodge et al. 1988, Hecky and Hesslein 1995, Vadeboncoeur et al 2001a). However, studies that have incorporated benthic-pelagic links by fishes in models of lake food webs have repeatedly demonstrated the importance of benthic subsidies on the effects of fishes in pelagic habitats.

To demonstrate the generality of habitat coupling provided by fishes in lakes, we compiled data from the literature to evaluate the relative importance of benthic prey in the diets of twelve freshwater fish species that are common in North American lakes. This survey represents a synthesis of other papers that provided compilations of diet information for a variety of fishes from lakes throughout North America (Schindler and Eby 1997, Vander Zanden et al. 1997). We defined benthic prey as those taxa whose life history and morphology are adapted largely to living on lake bottoms. This summary of prey sources demonstrated that benthic habitats are often the most important source of energy to a variety of common fish species (Fig. 3). The mean contribution of benthic prey to each fish species ranged from $18 \%$ to $90 \%$ of biomass, and averaged $55 \%$ across all species. This result is an extension of Hecky and Hesslein's (1995) finding that demonstrated the importance of benthic prey sources using carbon stable isotope analyses from nine lakes in Africa and North America. These results are important because they show that benthic resources are more important than planktonic resources in supporting fish production in lakes throughout North America. This result may not be widely appreciated by aquatic ecologists. The prevalence of benthic prey in the diets of fishes has several important consequences for individual, population and ecosystem processes in lakes (Table 1).

\section{Riparian linkages to aquatic habitats of lakes}

Although stream ecologists have developed paradigms that account explicitly for riparian-aquatic linkages, studies of the linkages between lakes and their riparian habitats are very rare. Litterfall from riparian vegetation can constitute a major source of organic matter to benthic and pelagic habitats in lakes. The importance of this input depends on the characteristics of the riparian habitats (e.g. development and species composition of forests), the degree of shoreline complexity, and the overall productivity of the aquatic system (Gasith and Hasler 1976). Most of these organic inputs are deposited as litterfall from the riparian vegetation. However, in some instances inputs of terrestrial insects can produce substantial subsidies of prey to aquatic predators and to lake nutrient cycles (Carlton and Goldman 1984, Cole et al. 1990).

Inputs of coarse woody debris (CWD) from riparian forests provide complex and unique habitat structure to the littoral zone of lakes. Coarse woody debris decomposes very slowly once it has entered aquatic habitats (Guyette and Cole 1999) and therefore accumulates over centuries on lakeshores. Densities of CWD larger 


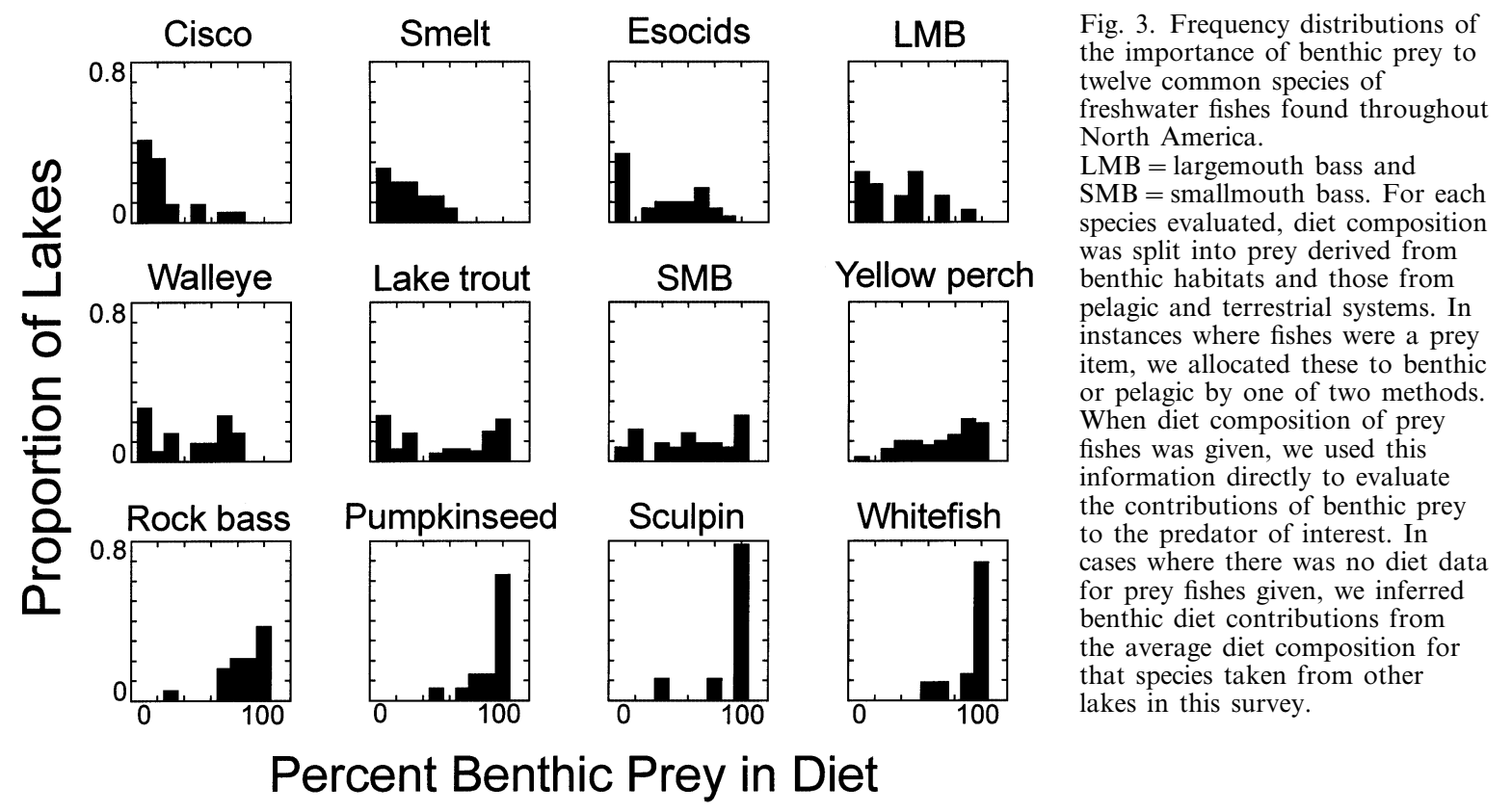

than $10 \mathrm{~cm}$ in diameter have been reported between 500-1100 per kilometer of shoreline for lakes with intact riparian forests (Christensen et al. 1996, Mallory et al. 2000). These inputs clearly have important effects on the diversity, structure, and productivity of benthic communities. For example, based on research with habitat complexity associated with macrophytes (Crowder and Cooper 1982, Persson 1993, Persson and Eklov 1995) we should expect that the increase in littoral habitat complexity associated with coarse woody debris will have substantial effects on predator-prey interactions among fishes and their invertebrate prey. Surprisingly, there has been almost no research to evaluate the roles of CWD as habitat in lake ecosystems.

Biological coupling from aquatic to riparian habitats of lakes are probably common but are poorly studied. Dispersal of aquatic invertebrates to riparian habitats of streams have been shown to be major sources of prey for riparian consumers (Nakano and Murakami 2001). Similar subsidies from lakes are probably equally common but not understood.

\section{Consequences of habitat coupling}

The important biological linkages among lake habitats have generally been overlooked in aquatic ecology (Lodge et al. 1988). Current models of trophic interactions do not include several of the mechanisms driving patterns of species interactions in the pelagic habitats of lakes (Table 1). Current studies of pelagic food webs try to evaluate how energy and nutrients flow via trophic interactions from primary producers to zooplankton grazers, to invertebrate and vertebrate zooplanktivores, and eventually to top predators, which are usually fishes. Fishes are ecologically important in terms of their effects on the composition and dynamics of aquatic communities and their role in regulating energy and nutrient flows (Hrbácek et al. 1961, Brooks and Dodson 1965, Zaret and Paine 1973, Persson et al. 1992, Carpenter and Kitchell 1993, Schindler et al. 1997a).

One important and demonstrative example of the importance of habitat coupling in the dynamics of aquatic communities is the role of fishes in trophic cascades. Trophic cascades result from changes in herbivory rates by zooplankton that result from shifts in the degree of size-selective predation on zooplankton in lakes (McQueen et al. 1989, Carpenter and Kitchell 1993, Persson et al. 1993). For example, zooplanktivorous fishes will preferentially reduce the densities of large herbivorous zooplankton (e.g. Daphnia spp.) and shift zooplankton communities to states dominated by small-bodied species (Brooks and Dodson 1965). Because the grazing rates of zooplankton communities are positively related to the average body size of zooplankton, predation-induced shifts to smaller bodied zooplankton communities results in reduced grazing pressure on phytoplankton and therefore higher phytoplankton biomass and production. These fish-mediated shifts in trophic interactions also result in changes to nutrient cycles that enhance nutrient regeneration to phytoplankton in lakes dominated by planktivorous fishes (Schindler et al. 1993, Vanni et al. 1997). In some cases, these predation-driven shifts in primary production and nutrient cycling can alter fundamental geo- 
chemical fluxes, such as exchange of carbon dioxide between lakes and the atmosphere (Schindler et al. 1997a).

One unappreciated feature of trophic cascades in lakes is that benthic resources subsidize many of the fish populations that induce pelagic trophic cascades in lakes (Schindler et al. 1996, Vanni 1996). While this may seem counterintuitive, it is an excellent example of the importance of habitat coupling. This phenomenon results from the opportunistic and flexible nature of fish predation. Piscivorous fishes will consume their preferred prey (i.e. other fishes) when available. However, when prey fishes become scarce due to intense predation pressure, piscivorous fishes will switch to feeding on benthic invertebrates (Hodgson and Kitchell 1987, Schindler et al. 1997b). Benthic resources maintain piscivore populations during times when their preferred prey are scarce. Thus, the alternate resources provided by benthic food webs stabilize piscivore populations by de-coupling them from the dynamics of their preferred prey (Schindler et al. 1997b, Post et al. 2000).

Planktivorous fish populations are often stabilized by benthic resources in the same way that piscivores are. For example, planktivorous fishes will preferentially feed on large-bodied zooplankton such as Daphnia until they become rare, at which point fish will switch to feeding on benthic resources (Persson et al. 1993, Stein et al. 1995, Roseman et al. 1996). Like piscivores, planktivore populations then become uncoupled from the dynamics of their preferred pelagic prey. In both cases of planktivory and piscivory, benthic prey may dominate the diets of the predators that induce pelagic trophic cascades. The absence of the preferred prey in diets may actually reflect a very strong ecological interaction that has driven the preferred prey to local extinction. Thus, the prevalence of certain prey in the diet of predators is probably a poor indicator of interaction strength between the predator and specific prey. In the case of lakes, benthic habitats provide the alternative resources that maintain planktivore and piscivore populations once they have driven their preferred pelagic prey to low densities or even local extinction. In essence, habitat coupling by fishes imparts stability to pelagic communities because these linkages reduce the high temporal variability in energy flow and nutrient cycling characteristic of pelagic communities (sensu Wetzel 1979).

Habitat coupling by fishes can also have important effects on nutrient cycles in lakes. Conventional models of nutrient recycling within the pelagic habitats of lakes emphasize recycling by zooplankton as the major source of nitrogen and phosphorus for nutrient-limited phytoplankton (Sterner et al. 1992). Important abiotic inputs include upwelling from deep waters, nutrient loading from sediments and atmospheric inputs (Lewis et al. 1984, Levine et al. 1986, Caraco et al. 1992, Jassby et al. 1994, Bootsma et al. 1996a). Nutrients from the foraging and digestive activities of fishes are rarely included because most studies assume that fishes derive all of their energy from their plankton prey and, therefore, cannot recycle significant quantities of nutrients compared to their zooplankton prey (Hudson et al. 1999). However, studies that have quantified nutrient flux from benthic feeding fishes have concluded that fish excretion of nitrogen and phosphorus can constitute one of the major sources of nutrients needed to sustain phytoplankton growth during periods when allochthonous nutrient inputs are small (Brabrand et al. 1990, Reinertsen et al. 1990, Carpenter et al. 1992, Schindler et al. 1993, Vanni et al. 1997). These benthicderived nutrients do not arise from recycling from within the water column of lakes. This flux is a 'new' source of nutrients (sensu Dugdale and Goering 1967) that is then incorporated and recycled within planktonic habitats (Vanni 1996).

A growing body of evidence suggests that food webs in a wide variety of ecosystems are subsidized by energy and material flows from other, spatially distinct systems (Polis et al. 1997, 2001). These spatial subsidies can change the intensity and the stability of ecological interactions in restricted spatial locations. Spatial subsidies usually result from donor-controlled dynamics whereby feedbacks between habitats are asymmetric. Ecological interactions may be especially intense in habitats that are net recipients of energy or nutrients. We argue that spatially subsidized food webs exist in most lakes. The spatial coupling of food webs in lakes is asymmetric with dominant flows of energy and nutrients originating from benthic systems and progressing to pelagic systems. As described above, these habitat subsidies should have profound effects on planktonic community interactions, nutrient cycling, and the stability properties of food webs in lakes. In very large lakes, the reverse may be true, whereby dominant energy and nutrient flows originate from pelagic habitats and flow to benthic habitats (e.g. Fitzgerald and Gardner 1993). Determining how ecosystem size controls the magnitude and direction of habitat coupling in lakes remains largely unanswered.

\section{Evolutionary adaptations to benthic habitats}

Evolutionary characteristics of aquatic organisms reinforce the importance of benthic habitats in lake ecosystems. Here, we provide two brief examples that highlight the importance of benthic systems in the evolution of aquatic organisms.

Bootsma et al. (1996b) used carbon and nitrogen stable isotopes to assess the trophic differentiation within the fish community of Lake Malawi, Africa. This analysis showed that 17 of 20 fishes sampled from Lake Malawi had diets that were specialized on specific 
benthic taxa or microhabitats, while only 3 of 20 species were entirely pelagic in their trophic dependence (Fig. 4). This evidence suggests that benthic habitats provide a highly heterogeneous template to which evolution of trophic segregation may respond. Although we are not aware of similar studies from other systems, we suspect that benthic habitats support more diverse metazoan communities and trophic relationships than pelagic habitats because of the higher degree of habitat complexity in benthic systems.

Many species of freshwater plankton have complex life histories that involve both planktonic and benthic life stages. For typical plankton, the benthic life stage is usually a diapausing strategy (Fryxell 1983, Alekseev and Fryer 1996). Diapause life history strategies in plankton involve the production of a dormant egg that usually sinks to the lake sediments where it can

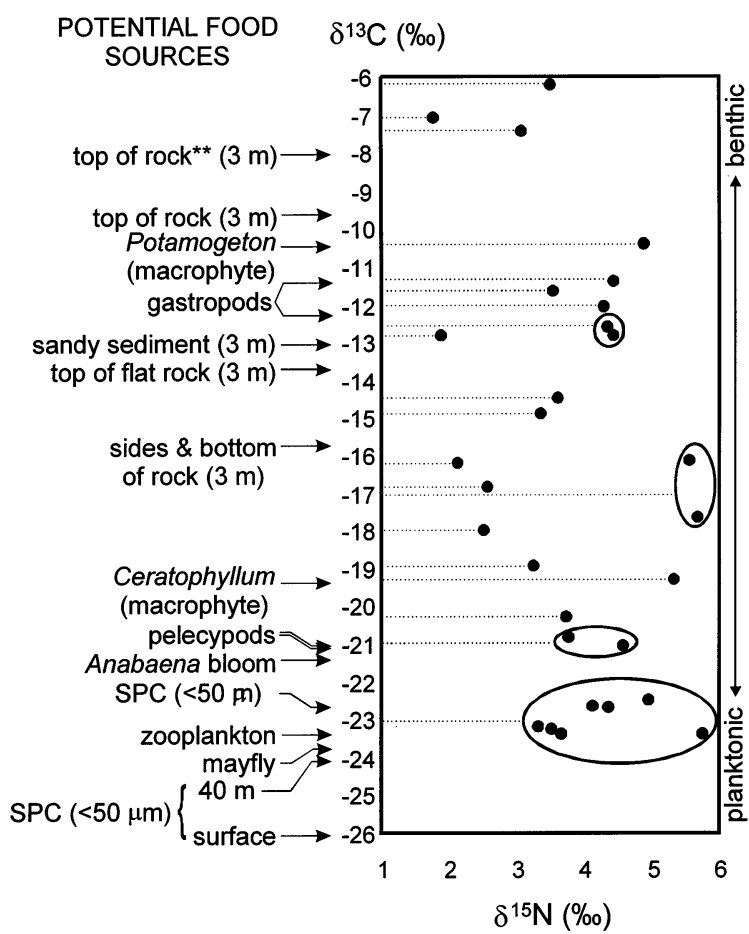

Fig. 4. An isotopic analysis of the fish community in Lake Malawi, Africa, relative to potential food sources (Bootsma et al. 1996b, redrawn with permission). Potential food sources are differentiated based on their carbon stable isotope distributions. Pelagic food sources have a carbon isotope signature $\left(\delta^{13} \mathrm{C}\right)$ between about $-21 \%$ and $-26 \%$. All other food sources are derived from benthic production and have carbon isotope signatures between $-21 \%$ and $-6 \%$. Intermediate values in predators may result from either specialization on a prey with intermediate $\delta^{13} \mathrm{C}$ value, or from mixed pelagic and benthic feeding. Each data point or group of circled data points represents an individual fish species. Seventeen of the 20 species studied had carbon isotope distributions that indicate either a strong dependence or obligate dependence on benthic food sources. See Bootsma et al. (1996b) for further description of the fish species represented in this study. remain for a time span of weeks to decades before hatching and re-invading the pelagic community. Among the Crustacea, Hairston and Cáceres (1996) found examples of diapause in 97 species across 17 orders. This diapause can in turn help to maintain biotic diversity by a mechanism impossible in the pelagic (Hairston et al. 1996, Cáceres 1997) and dampen algal-grazer population oscillations (McCauley et al. 1999), illustrating an important link between the benthos and pelagia. Many phytoplankton also have benthic resting cysts that can drive pelagic population dynamics upon their emergence from sediments (Sandgren 1988, Hansson 1996). From the standpoint of life history evolution in different habitats in lakes, benthic habitats provide a critical reservoir of diapausing individuals of most species of plankton. Furthermore, most of the aquatic insects in lake food webs are benthic and only a few have evolved a free-swimming planktonic behavior (e.g. Chironomidae) (Pennak 1978, Merritt and Cummins 1996). Thus, evolutionary and life history coupling between benthic and pelagic habitats is also critical in driving some of the dynamics of pelagic systems.

\section{Human effects on habitat coupling}

From a human perspective, lakes are highly desirable ecosystems for reasons that range from aesthetic to recreational and industrial (Postel and Carpenter 1997). As a result, lakes and their watersheds are often areas of intense human activity (Sala et al. 2000). There has been keen interest in reducing anthropogenic impacts on lakes and their watersheds, mostly focussed on reducing eutrophication due to increased nutrient loading from human and watershed sources (NRC 1992, Carpenter et al. 1998). Much less attention has been paid to the effects of humans on benthic and riparian habitats. Humans have a wide variety of effects on shoreline and benthic habitats of lakes (Table 2). These effects often occur simultaneously as lakes and their watersheds become developed for human activities. Therefore, we should expect that these effects cause substantial cumulative impacts to the benthic and riparian habitats of lakes. Human activities alter a variety of processes and structures in riparian habitats that may have important consequences for benthic communities and for entire aquatic systems through alterations to habitat coupling in lakes (Table 2). Ironically, many of these activities are intended to enhance the aesthetic value of lakes (NRC 1992).

Anthropogenic effects on littoral and riparian habitats have important consequences for processes occurring over the whole ecosystem. For example, a comparative study of lakes distributed across a 
Table 2. Common human activities that alter benthic and riparian habitats in lakes.

\begin{tabular}{|c|c|}
\hline Activity & Effects \\
\hline Deforestation of watersheds and riparian systems ${ }^{1}$ & $\begin{array}{l}\text { Increased erosion and siltation of benthic habitats. Loss of } \\
\text { source of large woody debris that represents future habitat } \\
\text { structure in benthic habitats. Increased nutrient and dissolved } \\
\text { organic carbon loading to lakes. }\end{array}$ \\
\hline $\begin{array}{l}\text { Removal of large woody debris from lakeshores and } \\
\text { lake beds }\end{array}$ & $\begin{array}{l}\text { Decreased complexity of littoral habitat. Loss of foraging } \\
\text { habitat, predation refuges, etc. }\end{array}$ \\
\hline Macrophyte removal & $\begin{array}{l}\text { Decreased complexity of littoral habitat. Loss of foraging } \\
\text { habitat, predation refuges, etc. }\end{array}$ \\
\hline Wetland drainage/removal ${ }^{1}$ & $\begin{array}{l}\text { Loss of critical ecotone between terrestrial and lentic systems. } \\
\text { Wetlands are often a key component of the littoral and } \\
\text { benthic systems of lakes. Nursery areas for fishes and birds } \\
\text { (e.g. northern pike spawn in wetlands during spring floods). } \\
\text { DOC loading to lakes. }\end{array}$ \\
\hline Exotic species introductions $s^{1,3}$ & $\begin{array}{l}\text { Effects vary depending on species. Organisms like zebra mussels } \\
\text { alter the benthic habitats of lakes displacing native mussels, } \\
\text { providing refuges for other invertebrates, and may increase } \\
\text { the productivity of benthic food webs and their subsequent } \\
\text { contributions to fish populations. Introductions of exotic } \\
\text { macrophytes alter habitat structure. For example, Eurasian } \\
\text { water milfoil can make benthic habitats less available to fishes } \\
\text { than prior to invasion. }\end{array}$ \\
\hline Eutrophication ${ }^{1,4}$ & $\begin{array}{l}\text { Increased phytoplankton biomass increases light attenuation that } \\
\text { reduces light availability for benthic algae growing at depth in } \\
\text { the water column. }\end{array}$ \\
\hline Dredging $^{1}$ & Removes river deltas disturbs sediments in lakes \\
\hline Water level management ${ }^{1}$ & $\begin{array}{l}\text { Restricted water level fluctuations may reduce seasonal flooding } \\
\text { that is important to nutrient regeneration and riparian/littoral } \\
\text { vegetation, and reduce wetland access to fishes and other } \\
\text { mobile organisms. }\end{array}$ \\
\hline
\end{tabular}

${ }^{1}$ (NRC 1992)

${ }^{2}$ (Christensen et al. 1996)

3 (Mills et al. 1994)

${ }^{4}$ (Carpenter et al. 1998)

lakeshore development gradient showed that the growth rates of two principal fish species decreased as the density of residential shoreline development increased (Fig. 5A, Schindler et al. 2000). Expectations about the response of fish growth rates to human lakeshore development based entirely on pelagic models would predict that fish growth rates should increase with the increased nutrient loads that follow from lakeshore development (Dillon and Rigler 1975). Additionally, if fish exploitation rates increase in parallel with lakeshore development, fish growth rates should also increase in response to lower fish densities and less intense competitive interactions among fishes. A previous study of these lakes documented a strong negative relationship between lakeshore development and the density of coarse woody debris in the littoral habitat of lakes (Fig. 5B, Christensen et al. 1996). Therefore, the most plausible explanation for the reduced fish growth rates in highly developed lakes was in response to reduced productivity of littoral habitats associated with loss of large woody debris (Schindler et al. 2000). Taken together, these results suggest that human activities seriously reduce the ability of lakes to support productive fish populations through the cumulative effects on lakeshores and benthic habitats, in addition to their impacts on water column chemistry.

\section{Management and restoration of aquatic ecosystems}

A major emphasis has emerged in the last decade for developing aquatic sciences applicable to the restoration and conservation of aquatic ecosystems (Naiman et al. 1995). A relatively recent US-National Research Council volume entitled "Restoration of Aquatic Ecosystems" provides strategies and guidance for restoration of aquatic resources in the United States (NRC 1992). The chapter on lakes outlines six major classes of stresses that lead to the degradation of aquatic ecosystems: excess nutrients, hydrological manipulation, siltation, exotic species introductions, acidification, and toxic contaminants. Of these, eutrophication, acidification and toxic pollution receive the vast majority of attention. Issues associated with reducing non-point source pollution of phosphorus and nitrogen (Carpenter et al. 1998) are especially well represented. However, the importance of habitat coupling is only mentioned briefly at the end of a list of the needs for future research. Very little additional attention is focused on issues and strategies for management and restoration of benthic and riparian habitats of lakes. We think some of this lack of attention is a reflection of our poor understanding of benthic habi- 
tats, relative to the pelagic systems, in lakes. Habitat complexity and heterogeneity represent a substantial challenge towards learning about benthic habitats. Greater value placed on benthic systems might ameliorate both the knowledge gaps and the management biases that emphasize pelagic systems.

Ecologists studying running waters emphasize interactions between riparian habitats and in-channel components of streams and rivers (Gregory et al. 1991, Naiman and Décamps 1997). One area of consensus emerging from this literature is that ecological interactions are intensified along the land-water interface associated with flowing water systems. Habitat coupling is critical for maintaining diverse and productive riparian and stream/river ecosystems. Management of flowing water systems now embraces this knowledge (Naiman et al. 2000). It is somewhat perplexing that lake ecologists have done little to incorporate riparian habitats into models of ecosystem dynamics and management. We believe lake ecologists should expand their views of lake ecosystems to include riparian habitats because many of the ecological interactions that are critical to
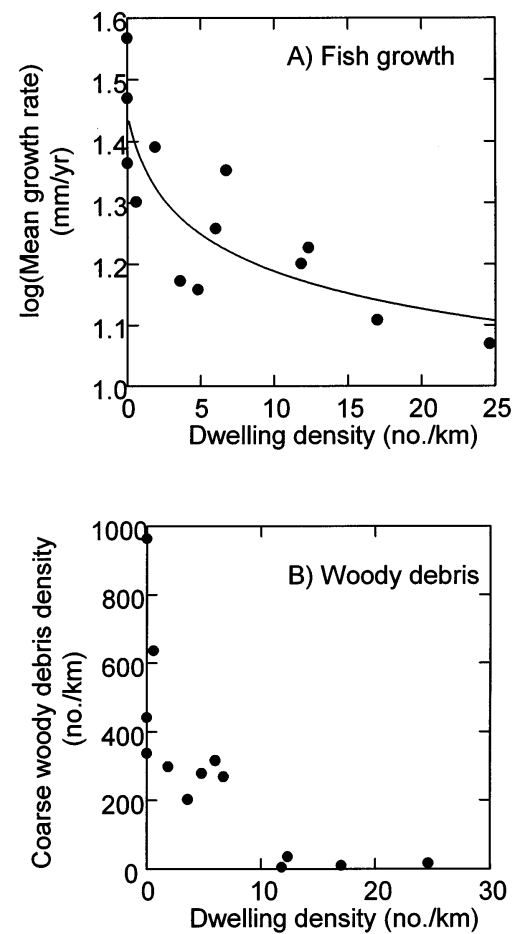

Fig. 5. (A) Relationship between the degree of shoreline residential development and the growth rates of bluegill sunfish (Lepomis macrochirus) in lakes from northern Wisconsin and the Upper Peninsula of Michigan (from Schindler et al. 2000 with permission). Growth rates are based on size-at-age determinations from scales of individual fishes and projected to the entire population based on the age distribution of individuals. (B) The density of large woody debris in the littoral habitats of the same lakes (from Christensen et al. 1996, used with permission). the integrity of lake ecosystems occur at the land-water interface. Processes that result in benthic-pelagic coupling are among the most obvious of these. In addition, lake management plans should incorporate riparian and benthic habitats as components that need to be protected to maintain ecosystem integrity. Instances where this is the case are rare.

We conclude by reiterating that aquatic sciences have a lengthy and diverse history emphasizing an ecosystem approach towards understanding the ecology of lakes. In fact, aquatic ecologists recognize the limitations of small-scale studies that do not account for the spatial and temporal complexity that characterize natural ecosystems (Schindler 1998). Processes that result in habitat coupling will be relevant at certain temporal and spatial scales and not at others. For example, benthic-pelagic coupling will have minimal effects on phytoplankton growth dynamics on the sub-hourly time scales that characterize nutrient uptake, while immigration from benthic resting stages will have profound effects on phytoplankton population dynamics over seasonal time scales (Hansson 1996). In contrast, inputs of woody debris to benthic habitats are realized over century-long time scales (Guyette and Cole 1999) and restoration of lakes with simplified shorelines (Christensen et al. 1996) will require active and patient management. Determining how habitat-coupling processes are manifest at different temporal scales will greatly enhance our understanding of the organization of aquatic ecosystems, and thus, our ability to manage aquatic resources wisely.

Like most disciplines of ecology, aquatic sciences are developing an impressive array of highly sophisticated tools that are being used to address increasingly complex problems in both scientific and policy arenas. For example, recent uses of natural stable isotope characteristics have greatly enhanced our ability to trace the sources and fates of organic matter and nutrients over the spatial and temporal scales relevant to natural processes in aquatic ecosystems (Peterson and Fry 1987, Hecky and Hesslein 1995). However, effective integration of processes that link the open water with lake bottoms and shorelines is still lacking and represents a critical goal for aquatic sciences.

Acknowledgements - We thank Peter Leavitt for enlightening discussions during the development of this paper, and Kate Howe, John Maron, Jon Moore, Bob Paine, Jennifer Ruesink, Anne Salomon and Amanda Stanley for helpful reviews of earlier versions of the manuscript. We are also grateful to the Andrew W. Mellon Foundation and the University of Washington - Royalty Research Fund for financial support.

\section{References}

Alekseev, V. R. and Fryer, G. 1996. Diapause in the Crustacea. - Hydrobiologia 320. 
Barko, J. W. and Smart, R. M. 1980. Mobilization of sediment phosphorus by submersed freshwater macrophytes. Freshwater Biol. 10: 229-238.

Boers, P., Van Ballegooijen, L. and Uunk, J. 1991. Changes in phosphorus cycling in a shallow lake due to food web manipulations. - Freshwater Biol. 25: 9-20.

Bootsma, H. A., Bootsma, M. J. and Hecky, R. E. 1996a. The chemical composition of precipitation and its significance to the nutrient budget of Lake Malawi. - In: Johnson, T C. and Odada, E. (eds), The limnology, climatology and paleoclimatology of the East African lakes. Gordon and Breach, Toronto, pp. 251-266.

Bootsma, H. A., Hecky, R. E., Hesslein, R. H. and Turner, G. F. 1996b. Food partitioning among Lake Malawi fishes as revealed by stable isotope analyses. - Ecology 77: 12861290.

Brabrand, Å., Faafeng, B. A. and Nilssen, J. P. M. 1990. Relative importance of phosphorus supply to phytoplankton production: fish excretion versus external loading. Can. J. Fish. Aquat. Sci. 47: 364-372.

Brooks, J. L. and Dodson, S. I. 1965. Predation, body size, and composition of plankton. - Science 150: $28-35$

Cáceres, C. E. 1997. Temporal variation, dormancy and coexistence: a field test of the storage effect. - Proc. Natl. Acad. Sci. 94: 9171-9175.

Caraco, N. F., Cole, J. J. and Likens, G. E. 1992. New and recycled primary production in an oligotrophic lake insights for summer phosphorus dynamics. - Limnol Oceanogr. 37: 590-602.

Carlton, R. G. and Goldman, C. R. 1984. Effects of a massive swarm of ants on ammonium concentrations in a subalpine lake. - Hydrobiologia 111: 113-117.

Carpenter, S. R. 1980. Enrichment of Lake Wingra, Wisconsin, by submerged macrophytes decay. - Ecology 61 $1145-1155$.

Carpenter, S. R. and Kitchell, J. F. 1993. The trophic cascade in lakes. - Cambridge Univ. Press.

Carpenter, S. R., Caraco, N. F., Correll, D. L. et al. 1998 Nonpoint pollution of surface waters with phosphorus and nitrogen. - Ecol. Appl. 8: 559-568.

Carpenter, S. R., Cottingham, K. L. and Schindler, D. E. 1992. Biotic feedbacks in lake phosphorus cycles. - Trends Ecol. Evol. 7: 332-336.

Christensen, D. L., Herwig, B. R., Schindler, D. E. and Carpenter, S. R. 1996. Impacts of lakeshore residential development on coarse woody debris in north temperate lakes. - Ecol. Appl. 6: 1143-1149.

Cole, J. J., Caraco, N. F. and Likens, G. E. 1990. Short-range atmospheric transport - a significant source of phosphorus to an oligotrophic lake. - Limnol. Oceanogr. 35: 1230 1237.

Covich, A. P., Palmer, M. A. and Crowl, T. A. 1999. The role of benthic invertebrate species in freshwater ecosystems. BioScience 49: 119-127.

Crowder, L. B. and Cooper, W. E. 1982. Habitat structural complexity and the interaction between bluegills and their prey. - Ecology 63: 1802-1813.

Dillon, P. J. and Rigler, F. H. 1975. A simple method for predicting the capacity of a lake for development based on lake trophic status. - J. Fish. Res. Board Can. 32: 15191531.

Dugdale, R. C. and Goering, J. J. 1967. Uptake of new and regenerated forms of nitrogen in primary productivity. Limnol. Oceanogr. 12: 196-206.

Eschmeyer, R. W. 1936. Essential considerations for fish management in lakes. - In: Anonymous (ed.), Proceedings from the North American Wildlife Conference, U. S. Government Printing Office, pp. 332-339.

Fisher, S. G. and Likens, G. E. 1973. Energy flow in Bear Brook, New Hampshire: an integrative approach to stream ecosystem metabolism. - Ecol. Monogr. 43: 421-439.

Fitzgerald, S. A. and Gardner, W. S. 1993. An algal carbon budget for pelagic-benthic coupling in Lake Michigan. Limnol. Oceanogr. 38: 547-560.
Fryxell, G. A. 1983. Survival strategies of the algae. - Cambridge Univ. Press.

Gasith, A. and Hasler, A. D. 1976. Airborne litterfall as a source of organic matter in lakes. - Limnol. Oceanogr. 21: $253-258$

Gregory, S. V., Swanson, F. J., McKee, W. A. and Cummins, K. W. 1991. An ecosystem perspective of riparian zones: focus on links between land and water. - BioScience 41: $540-551$.

Guyette, R. P. and Cole, W. G. 1999. Age characteristics of coarse woody debris (Pinus strobus) in a lake littoral zone. - Can. J. Fish. Aquat. Sci. 56: 496-505.

Hairston, N. G., Jr. and Cáceres, C. E. 1996. Distribution of crustacean diapause: micro- and macroevolutionary pattern and process. - Hydrobiologia 320: 27-44.

Hairston, N. G., Jr., Ellner, S. and Kearns, C. M. 1996. Overlapping generations: the storage effect and the maintenance of biotic diversity. - In: Rhodes, O. E. Jr., Chesser, R. K. and Smith, M. H. (eds), Population dynamics in ecological space and time. Univ. of Chicago Press, pp. 109-145.

Hanson, J. M. and Leggett, W. C. 1982. Empirical prediction of fish biomass and yield. - Can. J. Fish. Aquat. Sci. 39: 257-263.

Hansson, L. A. 1996. Algal recruitment from lake sediments in relation to grazing, sinking and dominance patterns in the phytoplankton community. - Limnol. Oceanogr. 41: $1312-1323$

Hasler, A. D. 1975. Coupling of land and water systems. Springer-Verlag.

Hecky, R. E. and Hesslein, R. H. 1995. Contributions of benthic algae to lake food webs as revealed by stable isotope analysis. - J. N. Am. Benth. Soc. 14: 631-653.

Hodgson, J. R. and Kitchell, J. F. 1987. Opportunistic foraging by largemouth bass (Micropterus salmoides). - Am. Midland Nat. 118: 323-336.

Hrbácek, J., Dvorakova, M., Korinek, V. and Prochazkova, L. 1961. Demonstration of the effect of the fish stock on the species composition of zooplankton and the intensity of metabolism of the whole plankton assemblage. - Verh. Internat. Limnol. 14: 192-195.

Hudson, J. J., Taylor, W. D. and Schindler, D. W. 1999. Planktonic nutrient regeneration and cycling efficiency in temperate lakes. - Nature 400: 659-661.

Jassby, A. D., Reuter, J. E., Axler, R. P. et al. 1994. Atmospheric deposition of nitrogen and phosphorus in the annual nutrient load of Lake Tahoe (California Nevada). Water Resources Res. 30: 2207-2216.

Kitchell, J. F., Schindler, D. E., Herwig, B. R. et al. 1999. Nutrient cycling at the landscape scale: the role of diel foraging migrations by geese at the Bosque del Apache National Wildlife Refuge, New Mexico. - Limnol. Oceanogr. 44: 828-836.

Lake, P. S., Palmer, M. A., Biro, P. et al. 2000. Global change and the biodiversity of freshwater ecosystems: impacts on linkages between above-sediment and sediment biota. BioScience 50: 1099-1107.

Levine, S. N., Stainton, M. P. and Schindler, D. W. 1986. A radiotracer study of phosphorus cycling in a eutrophic Canadian Shield lake, Lake 227, Northwestern Ontatio. Can. J. Fish. Aquat. Sci. 43: 366-378.

Lewis, W. M., Grant, M. C. and Saunders, J. F. 1984 Chemical patterns of bulk atmospheric deposition in the state of Colorado. - Water Resources Res. 20: 1691-1704.

Likens, G. E. 1985. An ecosystem approach to aquatic ecology: Mirror Lake and its environment. - Springer-Verlag.

Lodge, D. M., Barko, J. W., Strayer, D. et al. 1988. Spatial heterogeneity and habitat interactions in lake communities. - In: Carpenter, S. R. (ed.), Complex interactions in lake communities. Springer-Verlag, pp. 181-208. 
MacIsaac, H. J., Sprules, W. G., Johansson, O. E. and Leach, J.H. 1992. Filtering impacts of larval and sessile zebra mussels (Dreissena polymorpha) in Western Lake Erie. Oecologia 92: 30-39.

MacIsaac, H. J., Lonnee, C. J. and Leach, J. H. 1995. Suppression of microplankton by zebra mussels - importance of mussel size. - Freshwater Biol. 34: 379-387.

Mallory, E. C., Ridgway, M. S., Gordon, A. M. and Kaushik, N. K. 2000. Distribution of woody debris in a smal headwater lake, central Ontario, Canada. - Arch. Hydrobiol. 148: 587-606.

McCauley, E., Nisbet, R. M., Murdoch, W. W. et al. 1999 Large-amplitude cycles of Daphnia and its algal prey in enriched environments. - Nature 402: 653-656.

McQueen, D. J., Johannes, M. R. S., Post, J. R. et al. 1989 Bottom-up and top-down impacts on freshwater pelagic community structure. - Ecol. Monogr. 59: 289-309.

Merritt, R. W. and Cummins, K. W. 1996. An introduction to the aquatic insects of North America. - Kendall/Hunt.

Mills, E. L., Leach, J. H., Carlton, J. T. and Secor, C. L. 1994 Exotic species and the integrity of the Great Lakes: lessons from the past. - BioScience 44: 666-676.

Naiman, R. J. and Décamps, H. 1997. The ecology of interfaces: Riparian zones. - Annu. Rev. Ecol. Syst. 28: 621658.

Naiman, R. J., Magnuson, J. J., McKnight, D. M. and Stanford, J. A. 1995. The freshwater imperative: a research agenda. - Island Press.

Naiman, R.J., Bilby, R.E. and Bisson, P.A. 2000. Riparian ecology and management in the Pacific coastal rain forest - BioScience 50: 993-1011.

Nakano, S. and Murakami, M. 2001. Reciprocal subsidies: dynamic interdependence between terrestrial and aquatic food webs. - Proc. Natl. Acad. Sci. 98: 166-170.

Nalepa, T. F. 1989. Estimates of macroinvertebrate biomass in Lake Michigan. - J. Great Lakes Res. 15: 437-443.

Nalepa, T. F., Gardner, W. S. and Malczyk, J. M. 1983 Phosphorus release by three kinds of benthic invertebrates: effects of substrate and water medium. - Can. J. Fish. Aquat. Sci. 40: 810-813.

National Research Council. 1992. Restoration of aquatic ecosystems: science, technology and public policy. - National Academy Press.

Palmer, M. A., Covich, A. P., Lake, S. et al. 2000. Linkages between aquatic sediment biota and life above sediments as potential drivers of biodiversity and ecological processes. BioScience 50: 1062-1075.

Pennak, R. W. 1978. Fresh-water invertebrates of the United States. - John Wiley and Sons.

Persson, L. 1993. Predator-mediated competition in prey refuges - the importance of habitat dependent prey resources. - Oikos 68: 12-22

Persson, L. and Eklov, P. 1995. Prey refuges affecting interactions between piscivorous perch and juvenile perch and roach. - Ecology 76: 70-81.

Persson, L., Diehl, S., Johansson, L. et al. 1992. Trophic interactions in temperate lake ecosystems - a test of foodchain theory. - Am. Nat. 140: 59-84.

Persson, L., Johansson, L., Andersson, G. and Hamrin, S. F. 1993. Density dependent interactions in lake ecosystems whole lake perturbation experiments. - Oikos 66: 193-208.

Peterson, B. J. and Fry, B. 1987. Stable isotopes in ecosystem studies. - Ann. Rev. Ecol. Syst 18: 293-320.

Polis, G. A., Anderson, W. B. and Holt, R. D. 1997. Towards an integration of landscape and food web ecology: the dynamics of spatially subsidized food webs. - Annu. Rev. Ecol. Syst. 28: 289-316.

Polis, G. A., Hurd, S. D., Jackson, C. T. and Sanchez-Pinero, F. 1998. Multifactor population limitation: variable spatia and temporal control of spiders on Gulf of California islands. - Ecology 79: 490-502.

Polis, G. A., Power, M. E. and G. A Huxel, (eds). 2001. Food webs at the landscape level. - Oxford Univ. Press.
Post, D. M., Connors, M. E. and Goldberg, D. S. 2000. Prey preference by a top predator and the stability of linked food chains. - Ecology 81: 8-14.

Postel, S. and Carpenter, S. R. 1997. Freshwater ecosystem services. - In: Daily, G. C. (ed.), Nature's services: societal dependence on natural ecosystems. Island Press, pp. 195 214

Rengefors, K., Karlsson, I. and Hansson, L. A. 1998. Algal cyst dormancy: a temporal escape from herbivory. - Proc. R. Soc. Lond. B 265: 1353-1358.

Reinertsen, H., Jensen, H., Koksvik, J. I. et al. 1990. Effects of fish removal on the limnetic ecosystem of a eutrophic lake. - Can. J. Fish. Aquat. Sci. 47: 166-173.

Roseman, E. F., Mills, E. L., Forney, J. L. and Rudstam, L. G. 1996. Evaluation of competition between age-0 yellow perch (Perca flavescens) and gizzard shad (Dorosoma cepedianum) in Oneida Lake, New York. - Can. J. Fish. Aquat. Sci. 53: $865-874$.

Ryder, R. A. 1965. A method for estimating the potential fish production of north-temperate lakes. - Trans. Am. Fish. Soc. 94: 214-218.

Sala, O. E., Chapin, F. S., Armesto, J. J. et al. 2000. Global biodiversity scenarios for the year 2100 . - Science 287 : $1770-1774$

Sandgren, C. D. 1988. Growth and reproductive strategies of freshwater phytoplankton. - Cambridge Univ. Press.

Sand-Jensen, K. and Borum, J. 1991. Interactions among phytoplankton, periphyton and macrophytes in temperate freshwaters and estuaries. - Aq. Bot. 41: 137-175.

Scheffer, M., Hosper, S. H., Moss, B. and Jeppesen, E. 1993. Alternative equilibria in shallow lakes. - Trends Ecol. Evol. 8: $275-279$.

Schindler, D. E. and Eby, L. A. 1997. Interactions between growth rates and the stoichiometry of fishes and their prey: implications for nutrient recycling. - Ecology 78: 18161831

Schindler, D. E., Kitchell, J. F., He, X. et al. 1993. Food-web structure and phosphorus cycling in lakes. - Trans. Am. Fish. Soc. 122: 756-772.

Schindler, D. E., Carpenter, S. R., Cottingham, K. L. et al. 1996. Food web structure and littoral zone coupling to pelagic trophic cascades. - In: Polis, G. A. and Winemiller, K. O. (eds), Food webs: integration of patterns and dynamics. Chapman \& Hall, pp. 96-105.

Schindler, D. E., Carpenter, S. R., Cole, J. J. et al. 1997a. Influence of food web structure on carbon exchange between lakes and the atmosphere. - Science 277: 248-250.

Schindler, D. E., Hodgson, J. R. and Kitchell, J. F. 1997b. Density-dependent changes in individual foraging specialization of largemouth bass. - Oecologia 110: 592-600.

Schindler, D. E., Geib, S. I. and Williams, M. R. 2000. Patterns of fish growth along a residential development gradient in north temperate lakes. - Ecosystems 3: 229-237.

Schindler, D. W. 1998. Replication versus realism: the need for ecosystem-scale experiments. - Ecosystems 1: 323-334.

Smith, C. S. and Adams, M. S. 1986. Phosphorus transfer from sediments by Myriophyllum spicatum. - Limnol. Oceanogr. 31: $1312-1321$

Stein, R. A., DeVries, D. R. and Dettmers, J. M. 1995 Food-web regulation by a planktivore: exploring the generality of the trophic cascade hypothesis. - Can. J. Fish. Aquat. Sci. 52: 2518-2526.

Sterner, R. W., Elser, J. J. and Hessen, D. O. 1992. Stoichiometric relationships among producers, consumers and nutrient cycling in pelagic ecosystems. - Biogeochemistry 17: 49-67.

Stewart, D. J. and Binkowski, F. 1986. Dynamics of consumption and food conversion in Lake Michigan alewives. Trans. Amer. Fish. Soc. 115: 643-661.

Strayer, D. and Likens, G. E. 1986. An energy budget for the zoobenthos of Mirror Lake, New Hampshire. - Ecology 67: $303-313$.

Vadeboncoeur, Y., Vander Zanden, M. J. and Lodge, D. M. 2001a. Putting the lake back together: reintegrating benthic pathways into lake food web models. - BioScience 52: $44-54$. 
Vadeboncoeur, Y., Lodge, D. M. and Carpenter, S. R. 2001b. Whole-lake fertilization effects on distribution of primary production between benthic and pelagic habitats. - Ecology 82: $1065-1077$.

Vander Zanden, M. J., Cabana, G. and Rasmussen, J. B. 1997 Comparing trophic position of freshwater fish calculated using stable nitrogen isotope ratios $(\mathrm{d} 15 \mathrm{~N})$ and literature dietary data. - Can. J. Fish. Aquat. Sci. 54: 1142-1158.

Vanni, M. J. 1996. Nutrient transport and recycling by consumers in lake food webs: implications for algal communities. - In: Polis, G. A. and Winemiller, K. O. (eds), Food webs: integration of patterns and dynamics. Chapman \& Hall, pp. 81-95.

Vanni, M. J., Layne, C. D. and Arnott, S. E. 1997. "Top-down" trophic interactions in lakes: Effects of fish on nutrient dynamics. - Ecology 78: 1-20.

Wells, L. and Beeton, A. M. 1963. Food of the bloater, Coregonus hoyi, in Lake Michigan. - Trans. Amer. Fish. Soc. 92: $245-255$.
Werner, E. E., Gilliam, J. F., Hall, D. J. and Mittelbach, G. G. 1983. An experimental test of the effects of predation risk on habitat use in fish. - Ecology 64: 15401548.

Wetzel, R. G. 1979. The role of the littoral zone and detritus in lake metabolism. - Arch. Hydrobiol. 13: 145161.

Wetzel, R. G. 1990. Land-water interfaces: metabolic and limnological regulators. - Verh. Internat. Limnol. 24: $6-24$.

Wiens, J. A., Crawford, C. S. and Gosz, J. R. 1985. Boundary dynamics: a conceptual framework for studying landscape ecosystems. - Oikos 45: 421-427.

Willson, M. F., Gende, S. M. and Marson, B. H. 1998. Fishes and the forest. - Bioscience 48: 455-462.

Wootton, R. J. 1990. Ecology of teleost fishes. - Chapman and Hall.

Zaret, T. M. and Paine, R. T. 1973. Species introduction in a tropical lake. - Science 218: 444-445. 